\title{
Pembuatan Bakso Sehat dengan Penambahan Buah Naga Merah bagi Masyarakat Di Desa Srikaton, Kecamatan Pondok Kelapa, Bengkulu Tengah
}

\author{
Suharyanto', Edi Soetrisno', dan Yurike ${ }^{2^{*}}$ \\ ${ }_{1}^{1}$ Program Studi Peternakan, Universitas Bengkulu, 38371 Bengkulu, Indonesia \\ $2^{*}$ Program Pascasarjana Pengelolaan Sumber Daya Alam, Universitas Bengkulu, 38371 Bengkulu, Indonesia
}

\section{ARTICLE INFO}

Riwayat Artikel:

Draft diterima: 28 November 2021

Revisi diterima: 13 Desember 2021

Diterima: 20 Desember 2021

Tersedia Online: 27 Desember 2021

Corresponding author:

*yurikebosu@gmail.com

Citation: Suharyanto, Sutrisno. E, dan Yurike. 2021. Pembuatan Bakso Sehat dengan Penambahan Buah Naga Merah bagi Masyarakat Di Desa Srikaton, Kecamatan Pondok Kelapa, Bengkulu Tengah. ICOMES: Indonesian Journal of Community Empowerment and Service. 1(1), pp: 35-40

\begin{abstract}
ABSTRAK
Bakso merupakan produk olahan berbasis daging yang digemari masyarakat. Hal ini sangat positif karena dapat menjadi media peningkatan konsumsi protein hewani asal daging bagi masyarakat. Akan tetapi, popularitas bakso ini harus diimbangi dengan ketersediaanya dalam formula yang menyehatkan bagi konsumen. Permasalahan yang terjadi di Desa Srikaton, diantaranya: 1) Masih rendahnya kesadaran masyarakat memproduksi dan mengkonsumsi produk olahan alami yang menyehatkan; 2) Masih rendahnya kesadaran masyarakat dalam konsumsi protein yang berasal dari daging; 3) Di tengah pandemi Covid-19, masyarakat Desa Srikaton perlu ditingkatkan usaha keluarga untuk meningkatkan pendapatan keluarga. Berdasarkan permasalahan diatas solusi yang ditawarkan adalah melakukan pendampingan pelatihan Pembuatan Bakso Sehat dengan Penambahan Buah Naga Merah. Tujuan kegiatan ini adalah untuk mengenalkan manfaat dari pentingnya mengkonsumsi protein hewani dan untuk memanfaatkan buah naga merah dalam pembuatan bakso guna meningkatkan antioksidan, menjadi pengawet dan pewarna alami yang sangat menarik. Selain itu juga dapat meningkatkan pendapatan masyarakat karena pada dasarnya dapat dilakukan dengan skala industri rumah tangga dan menjadi usaha bagi masyarakat yang hidup di pedesaan. Kegiatan dilakukan dengan metode pemaparan materi, diskusi dan praktek. Hasil dari pengabdian ini adalah meningkatnya kesadaran masyarakat dalam memproduksi dan mengkonsumsi produk olahan alami yang menyehatkan serta terciptanya produk bakso dengan campuran buah naga yang bergizi. Perlu adanya keberlanjutan kegiatan ini terutama adanya pelatihan inovasi atau diversifikasi produk makananan lainnya.
\end{abstract}

Kata kunci: Bakso sehat; Buah naga merah; Diversifikasi; Inovasi

\section{ABSTRACT}

Meatballs are meat-based processed products that are favored by most people. This is very positive because it can be a medium for increasing the consumption of animal protein from meat for the community. However, the popularity of this meatball must be balanced with its availability in a healthy formula for consumers. Problems that occur in Srikaton Village, including 1) The low awareness of the community to produce and consume healthy natural processed products; 2) Public awareness is still low in the consumption of protein derived from meat; 3) In the midst of the Covid-19 pandemic, the people of Srikaton Village need to increase their family business to increase family income. Based on the problems above, the solution offered is to provide training for making healthy meatballs with the addition of red dragon fruit. The purpose of this activity is to introduce the benefits of the importance of consuming animal protein and to utilize red dragon fruit in making meatballs to increase antioxidants, become very attractive preservatives and natural dyes. Besides that, it can also increase people's income because basically it can be done with a home industry scale and become a business for people who live in rural areas. Activities are carried out using the method of material presentation, discussion and practice. The result of this community service is increasing public awareness in producing and consuming healthy natural processed products and the creation of meatball products with a nutritious mixture of dragon fruit. There is a need for the sustainability of this activity, especially the existence of innovation training or diversification of other food products. 


\section{PENDAHULUAN}

Pengembangan kapasitas masyarakat untuk menjadi komunitas yang mandiri dapat dilakukan dengan melakukan pembinaan dan pendampingan. Akan tetapi proses pembinaan dan pendampingan ini perlu diawali dengan introduksi suatu teknologi atau keterampilan baru yang dapat meningkatkan keberdayaan diri masyarakat (Bahua, 2015).

Introduksi teknologi yang memiliki potensi untuk dikenalkan kepada masyarakat suatu komunitas adalah produk olahan bakso. Bakso merupakan makanan berbasis daging yang sangat digemari oleh sebagian besar masyarakat. Hal ini sangat positif karena dapat menjadi media peningkatan konsumsi protein hewani asal daging bagi masyarakat. Akan tetapi, popularitas bakso ini harus diimbangi dengan ketersediaanya dalam formula yang menyehatkan bagi konsumen.

Salah satu bakso yang dengan formula menyehatkan adalah tanpa bahan pengawet dan mengandung produk alami yang sifatnya menunjang/memperkaya sifat fungsional bakso. Formula yang menyehatkan dapat dilakukan dengan penambahan bahan alami seperti produk tambahan pada proses pengolahan bakso. Salah satu produk tambahan yang potensial untuk dimanfaatkan adalah buah naga merah.

Buah Naga Merah (Hylocereus Polyrhizus) termasuk dalam buah yang memiliki kulit serta daging buah berwarna merah dan dapat digunakan sebagai pewarna alami dan antioksidan (Nizori et al., 2020). Antioksidan mengacu pada istilah yang terkandung dalam suatu zat yang melindungi tubuh dari serangan radikal bebas. Dalam buah naga merah terkandung Total Serat Pangan (TSP), semakin tinggi nilai TSP maka semakin tinggi aktivitas antioksidannya. Dengan mengkonsumsi 800-1000gram buah naga dapat meningkatkan kandungan antosianin pada tubuh manusia (Oktiarni., 2012).

Antosianin merupakan kelompok pigmen merah hingga ungu yang tersebar pada tumbuhan. Antosianin tergolong dalam pigmen yang disebut flavonoid. Dengan kandungan antosianin yang cukup tinggi, buah naga dapat digunakan sebagai pengganti produk pewarna alami (Nizori et al., 2020). Warna merupakan salah satu atribut yang mempengaruhi kualitas dan daya terima suatu makanan (Hayati et al., 2012). Penggunaan pewarna semakin meluas, terutama dalam makanan, minuman maupun tekstil, karena warna dapat menarik konsumen (Meilianti, 2018). Selain memberikan warna yang menarik, buah naga juga bagus untuk kesehatan tubuh.

Kesehatan adalah hal yang utama bagi manusia, apalagi di masa pandemik saat ini. Untuk itu perlu meningkatkan kesadaran masyarakat akan pola hidup sehat. Namun, di Desa Srikaton masih rendahnya kesadaran masyarakat dalam konsumsi makanan bergizi terutama protein yang berasal dari daging dan masih rendahnya kesadaran masyarakat memproduksi serta mengkonsumsi produk olahan alami yang menyehatkan. Selain itu, di tengah pandemi Covid-19, masyarakat Desa Srikaton perlu ditingkatkan usaha keluarga untuk meningkatkan pendapatan keluarga. Oleh karena itu, perlu diadakannya kegiatan pengabdian ini terhadap masyarakat Desa Srikaton, Kecamatan Pondok Kelapa, Kabupaten Bengkulu Tengah, Provinsi Bengkulu dengan memperkenalkan inovasi baru yaitu pembuatan bakso sehat dengan penambahan buah naga.

Desa Srikaton berada di Kecamatan Pondok Kelapa, Kabupaten Bengkulu Tengah, Provinsi Bengkulu. Luas wilayah keseluruhannya sekitar \pm 185 hektar, yang terdiri dari 160 hektar dataran rendah dan tanah berbukit seluas 25 hektar. Masyakat cenderung hanya bertumpu pada hasil pertanian atau peternakan. Oleh karena itu perlu pendampingan untuk meningkakan kapabilitas masyarakat Desa Srikaton salah satunya dengan cara pelatihan pembuatan bakso dengan ekstrak buah naga merah.

Tujuan pendampingan pelatihan pembuatan Bakso Sehat Dengan Sari Buah Naga di Desa Srikaton adalah untuk mengenalkan manfaat dari pentingnya mengkonsumsi protein hewani dan untuk memanfaatkan buah naga merah dalam pembuatan bakso guna meningkatkan antioksidan, meningkatkan anti bakteri serta menjadi pewarna alami yang sangat menarik. Selain itu juga dapat meningkatkan pendapatan masyarakat. Dengan diadakan pengabdian ini, besar harapan dapat membantu masyarakat dengan hasil bakso dari sari buah naga bisa dikembangkan oleh warga Desa Srikaton.

\section{METODE PELAKSANAAN Lokasi dan Waktu Pengabdian}

Kegiatan pelatihan pembuatan bakso sehat dengan sari buah naga ini dilaksanakan pada 9 November 2021. Lokasi pelaksanaan kegiatan bertempat di Balai Pertemuan Lestari Desa Srikaton.

\section{Metode Pelaksanaan}

Pengabdian ini akan dilaksanakan dengan metode ceramah atau pemaparan materi, tanya jawab, diskusi dan dilanjutkan dengan demonstrasi pembuatan bakso dengan metode demo masak. Pembuatan bakso sehat dengan ekstrak buah naga merujuk pada penelitian (Purnama dan Azizah, 2020).

Adapun langkah-langkah pembuatan bakso dengan ekstrak buah naga merah adalah sebagai berikut:

a. Penyiapan Buah Naga Merah

Buah diperoleh dari pasar, kemudian dikupas dari kulitnya dan diambil daging buahnya disesuaikan dengan kebutuhan dalam pembuatan bakso. Daging buah yang akan ditambahkan dilumatkan terlebih dahulu dengan menggunakan sendok, untuk kemudian dicampurkan pada adonan bahan. 
b. Pembuatan Bakso dengan Ekstrak Buah Naga Merah

Pembuatan bakso dengan penambahan buah naga dimulai dengan memotong daging (ayam atau sapi) dan dipisahkan dari tulang dan kulit. Daging yang sudah dipotong ditimbang sebanyak $50 \mathrm{~g}$ untuk digiling dengan bahan lainnya yaitu $15 \mathrm{ml}$ air es, dan buah naga merah sebanyak $10 \%$ dari berat daging. Hasil penggilingan tersebut digiling kembali dengan menambahkan bawang putih 2,5 gram, STPP 1 gram, merica 0,5 gram dan garam 0,5 gram. Hasil penggilingan kemudian diaduk dengan 15 gram tepung tapioka sampai terbentuk adonan yang rata. Selanjutnya adonan bakso dicetak/dibulatkan lalu direbus dengan air pada suhu $80^{\circ} \mathrm{C}$ selama 5 menit. Hasil bakso yang diperoleh dicicipi oleh masyarat.

\section{Alat dan Bahan}

a. Alat-alat ang di pakai dalam kegiatan ini, diantaranya:

1). Food processor (alat giling)

2). Kompor

3). Panci perebus

4). Pisau dapur

5). Sendok teh

6). Baskom plastik

7). Serokan

b. Bahan yang di gunakan dalam kegiatan ini, diantaranya:

1). Daging segar $1 \mathrm{~kg}$

2). Sagu atau tapioka 100-300 gram

3). Es 200-300 gram

4). STTP 3 gram

5). Bawang putih 2 siung, dihaluskan

6). Garam 30 gram

7). Merica 1 sendok teh

\section{Metode Analisis}

Untuk mengukur tingkat ketercapaian target, maka dilakukan evaluasi dan monintoring terhadap kegiatan yang telah dilakukan. Monitoring dilakukan saat pelaksanaan kegiatan pengabdian dan dilaksanakan dengan cara tim PPM turun langsung ke lapangan untuk memonitor apakah kegiatan yang dilakukan berjalan sesuai dengan target waktu dan hasil yang diharapkan. Selain monitoring juga dilakukan evaluasi terhadap pelaksanaan kegiatan.

\section{HASIL DAN PEMBAHASAN Gambaran Umum Desa Srikaton}

Desa Srikaton merupakan bagian daerah otonom dari Kecamatan Pondok Kelapa, Kabupaten Bengkulu Tengah. Sebagian besar penduduk Desa Srikaton didominasi oleh para transmigran dari Pulau Jawa (Yogyakarta). Selain itu, di Desa Srikaton juga terdapat penduduk yang berasal dari Padang, Medan dan warga lokal sekitar seprti Serawai, Rejang serta Lembak.

Sejak berdirinya Desa Srikaton dan kedatangan para pendatang dari Jawa, sebagian besar penduudk bermata pencaharian sebagai petani. Hal ini karena adanya alokasi lahan pertanian seluas 2 hektar yang disediakan oleh pemerintah. Selain itu juga didukung dengan sumber air yang cukup tersedia dan lahan yang subur membuat masyarakat memilih pertanian untuk mata pencaharian mereka. Sehingga saat ini sebagian besar masyarakat bekerja sebagai petani atau peternak.

\section{Potensi Pemberdayaan Masyarakat Desa Srikaton}

Pemberdayaan masyarakat adalah proses menjadikan masyarakat mandiri berdasarkan kemampuannya untuk meningkatkan kesejahteraannya. Proses pemberdayaan mengambil masyarakat sebagai pihak utama atau pusat pembangunan (Bahua, 2015). Huraerah (2011) menambahkan bahwa pemberdayaan masyarakat merupakan suatu proses dalam rangka memperkuat apa yang disebut dengan kemandirian masyarakat. Pada proses ini, masyarakat dibantu untuk menganalisis masalah yang mereka hadapi, membantu mereka menemukan alternatif pemecahan masalah tersebut, dan menunjukkan kepada mereka strategi untuk memanfaatkan berbagai kemampuan yang mereka miliki.

Kegiatan pemberdayaan masyarakat melalui pelatihan pembuatan bakso sehat dengan penambahan buah naga telah dilaksanakan pada bulan November 2021 yang diikuti oleh lebih kurang 30 peserta. Kegiatan diawali dengan penyuluhan atau pemaparan materi dan dilanjutkan dengan demonstrasi pembuatan bakso. Terlihat pada Gambar 1 masyarakat fokus mendengarkan pemaparan materi yang disampaikan. Berdasarkan pengamatan dari kegiatan pengabdian pada masyarakat di Desa Srikaton, terlihat masih rendahnya pemahaman masyarakat akan pentingnya konsumsi protein yang berasal dari daging dan masih rendahnya kesadaran masyarakat memproduksi dan mengkonsumsi produk olahan alami yang menyehatkan. Hal ini terlihat dari pertanyaan-pertanyaan yang didiskusikan selama kegiatan berlangsung.

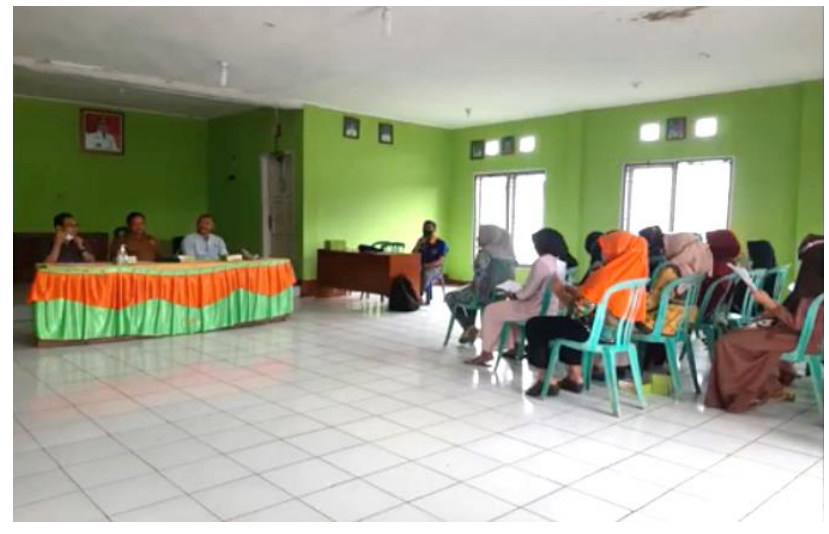

Gambar 1. Masyarakat dengan fokus mendengarkan pemaparan materi

Untuk itu, pemanfaatan buah naga merah ke dalam pembuatan bakso yang dilakukan di Desa Srikaton 
merupakan sebuah inovasi baru yang dapat meningkatkan kesadaran masyarakat dalam mengkonsumsi protein hewani dan menggunakan produk olahan yang alami. Selain itu juga dapat meningkatkan pendapatan masyarakat karena pada dasarnya dapat dilakukan dengan skala industri rumah tangga dan menjadi usaha bagi masyarakat yang hidup di pedesaan.

Bakso merupakan makanan yang banyak disukai oleh masyarakat dari berbagai usia dan kalangan. Bakso juga cukup mudah dibuat dan ditinjau dari segi gizinya, bakso juga memiliki nilai gizi tinggi (Firmasnyah, 2020). Bakso sehat berasal dari daging ayam atau daging sapi halal, segar tanpa bahan pengawet buatan. Kaya zat yang menyehatkan (tambahan bahan alami). Jika bahan lain yang digunakan kurang dari 50\%, maka kualitas bakso dapat dianggap baik. Berbagai bahan yang ditambahkan harus memenuhi syarat dan tidak memberikan efek samping bagi kesehatan. Dengan pemanfaatan buah naga merah dalam pembuatan bakso akan meningkatkan nilai tambah dari produk bakso.

Dalam pembuatan bakso buah naga merah bermanfaat untuk meningkatkan antioksidan, meningkatkan anti bakteri dan menjadi pewarna alami yang sangat menarik. Hal ini juga di dukung pada masa pandemic Covid-19 saat ini meningkatkan kesadaran masyarakat akan pentingnya mengkonsumsi makanan bergizi, sehingga pemanfaatan buah naga di dalam bakso mempunyai nilai jual yang tinggi. Buah naga banyak mengandung vitamin dan bahan mineral lainnya, yang dapat membantu meningkatkan daya tahan dan metabolisme. Vitamin B3 dipercaya mampu mengurangi kadar kolesterol pada tubuh, dimana sangat dibutuhkan untuk menetralisir kandungan kolesterol yang disebabkan oleh daging sapi (Oktora, dkk., 2008; Jamilah et al., 2011).

Buah yang berasal dari Meksiko ini juga dapat menurunkan gula darah, tanaman ini juga kaya akan karoten dan vitamin C yang merupakan antioksidan. Antioksidan pada buah naga dapat digunakan sebagai pengawet alami pada makanan (Jamilah et al., 2011). Masyarakat jarang menggunakan buah naga merah sebagai pengawet makanan alami, dan kebanyakan masyarakat hanya memanfaatkan buah naga sebagai pewarna alami (Wahyuni, 2011). Senyawa antibakteri pada buah naga merah yaitu saponin, alkaloid, flavonoid, tannin, dan terpenoid. Dalam pemberian buah naga sebagai pengawet alami dapat memberikan alternatif baru pengawet alami sebagai pengganti pengawet sintetis, sehingga mengurangi efek negatif terhadap resiko kesehatan pada manusia (Jaafar et al., 2009).

Antosianin merupakan senyawa flavonoid yang larut dalam air yang juga merupakan pigment warna pada tanaman terutama pada buah dan bunga. Warna yang ditimbulkan oleh antosianin yaitu dari ungu, pink, merah sampai biru (Tazzini, 2014). Zat antosianin yang terkandung dalam buah naga dapat dijadikan sebagai pilihan sumber pewarna alami untuk minuman, makanan, bahkan tekstil (Larahmah et al., 2019).

Pembuatan bakso sebagai produk pangan lain diharapkan mampu memperkenalkan buah naga kepada masyarakat dan khasiat yang terkandung di dalam buah naga. Kombinasi antara daging dan buah naga dalam pembuatan bakso ini sangat baik. Hal ini juga didukung dengan tingkat kesadaran masyarakat akan arti pentinya kesehatan, sehingga inovasi bakso dengan pemanfaatan buah naga ini sesuai dijadikan bisnis di masa sekarang maupun di masa yang akan datang.

Berdasarkan hasil pengabdian melalui diskusi dan demonstrasi pembuatan bakso dengan penambahan buah naga yang dilakukan pada umumnya masyarakat yang ikut sangat antusias dalam mengikuti kegiatan tersebut. Masyarakat memberikan respon positif terhadap produk olahan bakso buah naga ini. Berdasarkan pengamatan di lapangan terlihat saat pemaparan materi dan melakukan praktek pembuatan bakso dengan pemanfaatan buah naga banyak pertanyaan-pertanyaan yang harus dijelaskan secara rinci. Masyarakat juga antusias mempraktekan secara langsung pembuatan bakso dengan buah naga tersebut. Seperti yang terlihat pada Gambar 2. masyakat ikut andil mempraktekan langsung pembuatan bakso.

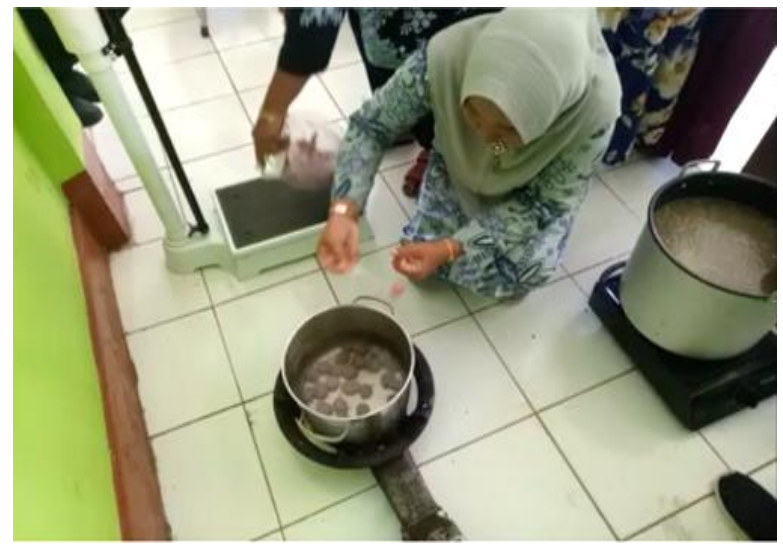

Gambar 2. Masyarakat antusias mempraktekan pembuatan bakso

Tingginya antusiasme masyarakat dalam mengikuti kegiatan pengabdian ini sangat memungkinkan usaha diversifikasi bakso dengan penambahan buah naga dilakukan di Desa Srikaton dapat dikembangkan. Inovasi pangan sehat dan bergizi memiliki prospek yang baik di masa mendatang, jika dibarengi dengan kerjasama yang baik antar instansi terkait sertadapat mendukung keberhasilan rencana ketahanan pangan nasional (Hamid, 2018).

\section{Solusi Pengembangan (Pemberdayaan) Masyakat Desa Srikaton}

Berdasarkan hasil pengamatan dan evaluasi terhadap aktivitas peserta pengabdian selama berlangsungnya kegiatan, maka dapat disimpulkan bahwa peserta sangat 
berminat untuk mengembangkan usaha pembuatan bakso dengan penambahan buah naga. Produk buah naga memiliki potensi pasar yang bagus untuk dikembangkan sebagai produk yang menguntungkan dan bermanfaat bagi kesehatan. Pada Gambar 3 terlihat masyarakat antusias mencoba bakso yang telah dibuat.

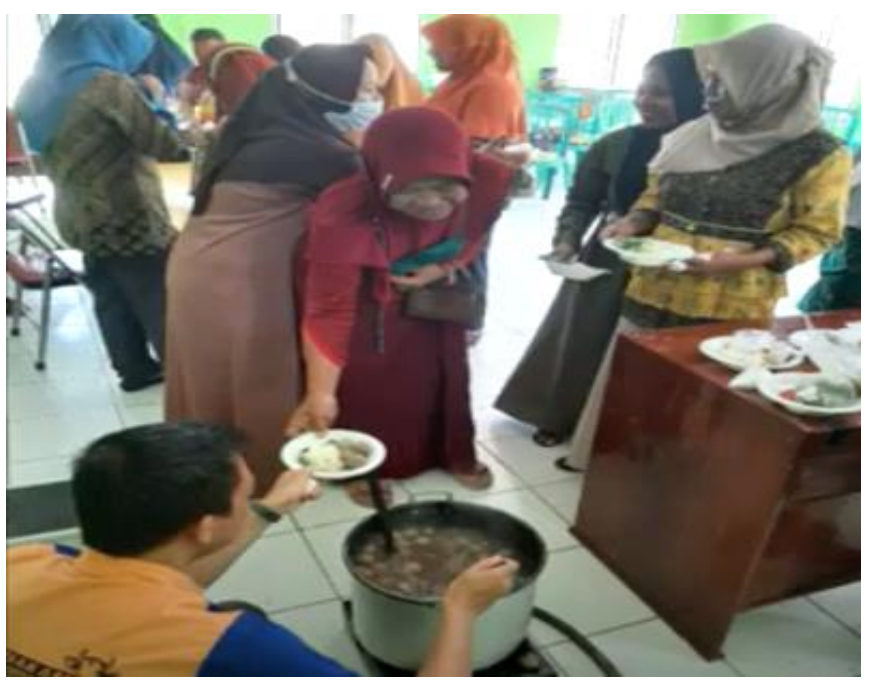

Gambar 3. Masyarakat mencoba bakso yang telah dibuat

Menurut Bahua (2005) inovasi baru akan diterima secara sosial oleh masyarakat, jika secara ekonomi inovasi itu akan menguntungkan usaha mereka, dan secara teknologi lokal inovasi tersebut dapat dilaksanakan oleh mereka, bahkan secara budaya inovasi tersebut dapat meningkatkan persatuan, persaudaraan keharmonisan hidup dimasyarakat setempat. Pengembangan usaha masyarakat ini dapat dilakukan dengan adanya tuntunan dan panduan yang tepat dalam pengolahan diversifikasi produk daging seperti pembuatan bakso dengan penambahan buah naga. Oleh karena itu, maka diperlukan buku panduan praktis teknologi tepat guna yang dapat di manfaatkan oleh masyarakat.

Di samping itu, pengembangan usaha masyarakat ini juga memerlukan pendampingan dan pembinaan agar produk yang dihasilkan bernilai jual dan bergizi tinggi tetap terjaga. Pembinaan diperlukan mulai dari pemilihan bahan baku yang baik, pengolahan yang higienis dan pengemasan produk yang menarik. Pengembangan usaha dapat dilakukan secara mandiri atau berkelompok.

\section{KESIMPULAN}

Penambahan buah naga pada pembuatan bakso merupakan inovasi dari bakso selain warnanya yang menarik juga menambah nilai gizi yang baik untuk kesehatan. Pemanfaatan buah naga pada pembuatan bakso juga membuka peluang usaha baru yang memiliki prospek untuk maju. Pengabdian ini diikti masyarakat dengan sangat antusias. Perlu adanya keberlanjutan kegiatan ini terutama adanya pelatihan inovasi atau diversifikasi produk makananan lainnya dalam mengembangkan perekonomian masyarakat di Desa Srikaton. Selain itu, kegiatan pengabdian masyarakat sebaiknya dilakukan secara berkesinambungan.

\section{UCAPAN TERIMAKASIH}

Penulis berterimakasih kepada LPPM Universitas Bengkulu yang mendanai kegiatan pengabdian ini. Terimakasih juga disampaikan kepada Program Pascasarjana Pengelolaan Sumber Daya Alam Universitas Bengkulu, semua anggota tim pengabdian, Kepala Desa dan Masyarakat Srikaton sehingga kegiatan ini dapat terlaksana dengan baik.

\section{DAFTAR PUSTAKA}

Bahua, M.I., (2015), Penyuluhan dan Pemberdayaan Petani Indonesia, Gorontalo: Ideas Publishing.

Firmansyah, M., (2020), Aplikasi Edible Coating Pada Bakso Ayam, EDUFORTECH, 5(2): 128-135.

Hamid, H., (2018), Manajemen Pemberdayaan Masyarakat, Makassar: De La Macca.

Hayati, R., Marliah, A., dan Rosita, F., (2012), Sifat Kimia dan Evaluasi Sensori Bubuk Kopi Arabika, Jurnal Florstek, 6675.

Huraerah, A., (2011), Pengorganisasian dan Pengembangan Masyarakat: Model dan Strategi Pembangunan Berbasis Kerakyatan, Edisi Kedua, Bandung: Humaniora

Jaafar, Ali, R., Nazri, M., dan Khairuddin, W., (2009), Proximate Analysis of Dragon Fruit (Hylecereuse polyhizus), American journal of Applide Sciences, 6: 13411346.

Jamilah, B., Shu, C.E., Kharindah, M., Dzulkifly, M.A., dan Noranizan, A., (2011), Physico-Chemical Characteristics of Red Pitaya (Hylocereus polyrhizus) Peel, International Food Research Journal, 18(1): 279-28.

Larahmah, J.L., Harahap, H.A., Pasaribu, L.Y., dan Batubara, M.S., (2019), Uji Kandungan Kimia Ekstrak Buah Karamunting (Melastoma malabathricum) Sebagai Upaya Menghasilkan Bahan Pewarna Alami Tekstil, Jurnal Penelitian dan Pembelajaran MIPA, 4(2): 104-109.

Meilianti, (2018), Isolasi Zat Warna (Antosianin) Alami Dari Buah Senduduk Akar (Melastoma Malabathricum L.) Dengan Metode Ekstraksi Maserasi Menggunakan Pelarut Etanol, Distilasi, 3(1): 8-15.

Nizori, A., Sihombing, N., dan Surhaini, (2020), Karakteristik Ekstrak Kulit Buah Naga Merah (Hylocereus Polyrhizus) Dengan Penambahan Berbagai Kosentrasi Asam Sitrat Sebagai Pewarna Alami Makanan, Jurnal Teknologi Industri Pertanian, 30(2): 228-233.

Oktiarni, D. (2012), Pemanfaatan Ekstrak Kulit Buah Naga Merah (Hylocereus polyrhizus sp.) Sebagai Pewarna Dan Pengawet Alami Mie Basah, Jurnal Gradien. 8 (2): 819824.

Oktora, R., Rahmawati, D., Nurseehafia, dan Widyaningsih, Y., (2008), Varian Buah Naga Dalam Bakso Sebagai Penetralisir Kolesterol. IPB: Bogor.

Purnama, F.D., dan Azizah, D.N., (2020), Mempelajari Konsentrasi Sari Daun Bayam Merah (Amaranthus Tricolor L.) Terhadap Karakteristik Bakso Ayam, EDUFORTECH, 5(2): 108-117. 
Tazzini, N., (2014), Anthocyanins: Definition, Structure And Ph. (Online), (http://www.tuscanydiet.net/2014/02/22/anthocyanins-definitionstructure-ph/, diakses 15 juni 2021).

Wahyuni, R., (2011)., Pemanfaatan Kulit Buah Naga Super Merah (Hylocereus costaricensis) Sebagai Sumber Antioksidan Dan Pewarna Alami Pada Pembuatan Jelly, Jurnal Teknologi Pangan, 2(1), 68-85. 